\title{
"Defining the tariff burden when providing the housing and utilities services in
}

Ukraine"

\begin{tabular}{|c|c|}
\hline AUTHORS & $\begin{array}{l}\text { levgen Balatskyi } \mathbb{D} \text { https://orcid.org/0000-0001-7039-1009 } \\
\mathbb{R} \text { https://publons.com/researcher/2455239/ievgen-balatskyi/ } \\
\text { Volodymyr Lavryk }\end{array}$ \\
\hline ARTICLE INFO & $\begin{array}{l}\text { levgen Balatskyi and Volodymyr Lavryk (2019). Defining the tariff burden when } \\
\text { providing the housing and utilities services in Ukraine. Public and Municipal } \\
\text { Finance, } 8(1), 112-119 \text {. doi:10.21511/pmf.08(1).2019.10 }\end{array}$ \\
\hline DOI & http://dx.doi.org/10.21511/pmf.08(1).2019.10 \\
\hline RELEASED ON & Friday, 17 January 2020 \\
\hline RECEIVED ON & Wednesday, 04 December 2019 \\
\hline ACCEPTED ON & Saturday, 28 December 2019 \\
\hline LICENSE & $\begin{array}{l}(c) \text { EY } \\
\text { This work is licensed under a Creative Commons Attribution } 4.0 \text { International } \\
\text { License }\end{array}$ \\
\hline JOURNAL & "Public and Municipal Finance" \\
\hline ISSN PRINT & $2222-1867$ \\
\hline ISSN ONLINE & $2222-1875$ \\
\hline PUBLISHER & LLC "Consulting Publishing Company "Business Perspectives" \\
\hline FOUNDER & LLC "Consulting Publishing Company "Business Perspectives" \\
\hline $0^{0}$ & $\begin{array}{l}\text { ニ: } \\
\text { ニ: }\end{array}$ \\
\hline NUMBER OF REFERENCES & NUMBER OF FIGURES \\
\hline 20 & 1 \\
\hline
\end{tabular}

(C) The author(s) 2022. This publication is an open access article. 


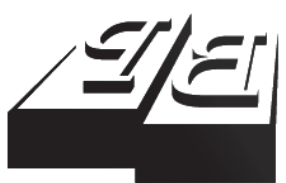

BUSINESS PERSPECTIVES



LLC "CPC "Business Perspectives" Hryhorii Skovoroda lane, 10, Sumy, 40022, Ukraine

www.businessperspectives.org

Received on: $4^{\text {th }}$ of December, 2019 Accepted on: $28^{\text {th }}$ of December, 2019

(C) Ievgen Balatskyi, Volodymyr Lavryk, 2019

Ievgen Balatskyi, Doctor in Economics, Department of Finance, Banking and Insurance, Sumy State University, Ukraine.

Volodymyr Lavryk, Ph.D. Student, Department of Finance, Banking and Insurance, Sumy State University, Ukraine.

\title{
DEFINING THE TARIFF BURDEN WHEN PROVIDING THE HOUSING AND UTILITIES SERVICES IN UKRAINE
}

\begin{abstract}
The article is devoted to studying the impact of different social and economic indicators on defining the population's tariff burden for housing and utilities services. The article analyzes the housing and utilities services provision system in Ukraine. It is noted that the majority of such companies are communally owned. The effect of different factors on defining the population's tariff burden was found. The impact was studied, and the need for considering the organizational, economically oriented, and social factors when defining the housing and utilities services tariffs was substantiated. The housing and utilities services tariff policy system, the procedure of the tariffs' structure developing, which is formed from economically reasonable costs of service provider's operating and financial activity (full target prime cost) and part of income, were studied. The financial relationships between the housing and utilities companies with budgets of different levels, first of all with local budgets, and state target funds; financial and credit institutions, and insurance companies, etc. were analyzed.
\end{abstract}

Keywords

JEL Classification tariffs, services, index, factors, state, social policy, Ukraine

R31, R51, R59

\section{INTRODUCTION}

Ukraine witnesses the insufficient level of financing, consumers paying untimely and incompletely for housing and utilities services provided, ineffective and irrational use of material resources. Herewith the outdated material and technical base, high level of noncurrent assets wearing, absence of sufficient amount of investment resources for upgrading the communally owned companies are meant. Also, the unsuccessful transformations took place when changing the housing and utilities companies' ownership forms, and the ineffective system for managing their activity fosters the need for constant state intervention into housing and utilities services sector and its reforming. In such conditions, apart from performing an effective economic activity, housing and utilities companies are called upon to implement the social constituent of state policy in the sphere of quality and timely housing and utilities services provision, which, in turn, requires creating more effective mechanisms of financial support for their activity.

\section{THEORETICAL BASIS} Creative Commons Attribution 4.0 International license, which permits unrestricted re-use, distribution, and reproduction in any medium provided the original work is properly cited.

State tariff policy is a normative phenomenon, so, among the ways for ensuring a comfortable existence, it is recommended for population to install the meters; perform the periodic energy audits; take part in energy saving support state program; install the individual heat supply 
stations; replacement of windows and doors, houses' warming; use of alternative energy sources.

Managing the finance of housing and utilities companies in Ukraine has certain peculiarities, such as multi-sectoral nature of these companies; close relationships with budget system, which are manifested in the need of subsidizing the companies from budgets of different levels, financing of different target programs; specific procedure of setting the housing and utilities services tariffs.

As Worstall (2013) notes, in the USA, during a long time, the housing and utilities companies functioned as state monopolies. In exchange for some limitations and legal or administrative supervision over retail tariffs, housing and utilities services providers used the monopoly at the market, where they set the prices and have no competitive pressure.

Nielsen (2019) emphasizes that monopolistic form is one of the most unique advantages that housing and utilities services use. Economically advantageous peculiarities of housing and utilities company made them good means for investors who aspire for reliable and competitive dividends and gradual development goals. He also noted that housing and utilities companies' income depends on the ownership form.

Mosquera Gutierres, Leme, Mota, and Santos (2019) studied the effect of the state on economic constituent of housing and utilities services, their income and costs, setting the prices and tariffs for their services.

Michelfeldera, Ahern, and D'Ascendis (2019) study the effect of regulatory mechanisms aimed at encouraging the consumers to preserve the natural gas, water, and electric energy, on decreasing the housing and utilities companies' income. The main question is whether such regulatory mechanisms affect the risk perceived by investor, total capital cost, and utility ratios of such goods.

Klien and Michaud (2019) analyze the effect of administrative consolidation on the effectiveness of water supply companies' operation. They noted that consolidation did not lead to a significant de- crease of prime cost. They also studied the potential reasons why housing and utilities companies did not achieve the scale economy.

The polluted environment gives impetus to using alternative energy sources. Beaufils and Pineau (2019) studied the effect of using solar batteries and electric cars on the income of electricity distribution companies and alternative structure of tariffs. The tariffs in the context of green electric energy were also studied by Salisbury and Toor (2016).

Fuentes-Cortés, Flores-Tlacuahuac, and PonceOrtega (2019) studied the pricing of housing and utilities services for end consumer, taking into account the subsidies and the effect of social, energy, and economic policy. New approaches to calculating the tariffs on housing and utilities services were also analyzed by Rábago and Valova (2018).

Ukrainian researchers emphasize that the housing and utilities services have a range of specific peculiarities, which characterize them as a complex, multielement, and dynamic organizational and economic system. Such peculiarities are high social significance; specific structure of companies' income and costs; simultaneous production and services consumption; guaranteed sale of services; local nature of production and services consumption; large service areas; diversity of operations.

Here one can select three groups of external and internal environment factors, which hinder the stable and effective development of housing and utilities services sector. First of all, it is a combination of organizational factors, which are based on dynamics and imperfection of regulatory and legal support of housing and utilities services sector functioning; absence of effectively functioning market of housing and utilities services; non-transparent management and tariff setting system; significant differentiation of tariffs and service providers in the context of regional constituent; inappropriate state control and housing and utilities services sector regulation.

Among the economic factors, which affect the housing and utilities services negatively, one should define the following: significant share of 
companies - natural monopolies, which causes low level of this sector's competitiveness; absence of interrelationship between the quality and the price of housing and utilities services; limited financial support; ineffective and irrational use of available financial resources; imbalance in calculations between the providers and the consumers; significant debt amounts for housing and utilities services provided; imperfect financial management system; excessive energy and material capacity of production; specificity of main funds formation, which leads to low level of their economic feasibility; incompetitiveness and low level of investment attractiveness.

Besides, the housing and utilities services sector is subject to the effect of a whole range of social factors, namely the need for ensuring proper level and volume of vital services; constant control on the part of sanitary and epidemiological and environmental structures; constant provision of a wide range of quality and competitive services according to consumers' urgent needs.

When characterizing the constituents of housing and utilities companies' financial relationships in Ukraine, one should note the financial relationships with budgets of different levels, first of all, with local budget, and state target funds; financial and credit institutions and insurance companies; with sectoral and corporate structures, wherein they can be included or be subordinate to them; founders, owners, members of associations; management structures (Poddierogin et al., 2008).

Irrespective of ownership form, as a result of performing main operating activity, connected with providing housing and utilities services, housing and utilities companies receive the income in the amount of the set tariff, which is covered at the account of consumers' payments for housing and utilities services (population and legal entities); sums of budget reimbursement in the part, which is given to cover the subsidies to housing and utilities companies or housing and utilities services consumers, granted in compliance with acting legislation; and other sources.

The local authorities, which have significant opportunities for affecting the financial and eco- nomic activity of housing and utilities companies and, in particular, formation of their income through the respective tariff policy, granting the budget subsidies, subventions, and benefits from the taxes paid and mandatory payments, play the defining role in finance management system in this sector (Kozachok, 2011).

When characterizing the housing and utilities services as a basis of human life social sphere, one should note that in Ukraine, it is one of least modernly equipped economic sectors, and requires attracting the significant material, labor, and financial resources. The crisis phenomena in the society and residual principle for financing this sector have led to further significant aggravation of its problems.

As the majority of housing and utilities infrastructure subjects in Ukraine are communally owned, it is the housing and utilities services sector that should be in priority among the tasks, which are delegated to local authorities. This will enable to fulfill the main goal of housing and utilities services - providing the population with quality services in the sector of heat, water, energy supply, garbage disposal, road facilities, housing preparation and repair.

One of the key problems, which should be solved both now and in future, is creating the effective financial support system, aimed at defining the sufficient level of budget financing and opportunities for attracting additional financial resources.

The article aims at assessing the impact of social and economic indicators on defining the population's tariff burden for housing and utilities services.

\section{RESULTS}

One of the key problems of housing and utilities companies functioning and ensuring their breakeven activity is formation and implementation of tariff policy in housing and utilities services sector. In Ukraine, state regulation of prices for housing and utilities services is performed in compliance with Regulation of the Cabinet of Ministers of Ukraine as of December 25, 1996 No. 1548 "On 
authorizing executive bodies to regulate prices (tariffs)" (Rybalko, 2009).

In the conditions of decentralization and reforming the local self-government system, the authorized central executive bodies, National Energy and Utilities Regulatory Commission and local authorities are entrusted with the role of setting and approving the tariffs for housing and utilities services. NEURC is the state authority, which regulates the activity in energy and utilities sector and, in particular, sets the tariffs for housing and utilities services for subjects of natural monopolies and economic entities at related markets, with this authority being entrusted with licensing their activity. Therefore, the authorized central executive bodies, and in cases stipulated by Law of Ukraine "On housing and utilities services" as of June 24, 2004 No. 1875-VII, by NEURC, which regulates the activity in energy and utilities sector, set the tariffs/prices for housing and utilities services (centralized cold water supply, centralized hot water supply, sewerage (using the house systems), gas supply, centralized heating, and garbage disposal, etc.) (Rudchenko, 2011). Local authorities set the tariffs at the respective territory for houses and adjoining territories maintenance (cleaning of house premises and adjoining territory, sanitary and technical maintenance, house networks, elevators' maintenance, common areas lighting, current repair, garbage disposal, etc.), houses or groups of houses' maintenance (house management, concluding the service contracts, control over contract terms fulfillment, etc.); houses' repair (replacement and reinforcement of structures and networks' elements, their reconstruction, renewal of bearing constructions elements' capacity, etc.) services (Sokyrynska, 2003).

At the level of housing cooperatives, prices/tariffs are set exclusively according to the contract (understandings between parties), except for services for which the state bodies or local authorities set the regulated prices/tariffs according to acting legislation.

Setting the tariffs for housing and utilities services is based on annual output targets and providing the respective types of services taking into account the rates of provided services volume change according to their separate types (heat en- ergy, water supply, sewerage) for the last five years and forecast calculations of such services volumes change and based on economically justified target prime cost (Nekhaychuk, n.d.). Herewith, the costs for producing separate types of housing and utilities services are target, taking into account such factors as state industry standards (norms of costs, resources); technical and economic calculations and estimates; system of producers and service consumers taxation; macroparameters of social and economic development (price indexes, inflation index, exchange rates fluctuations, subsistence minimum, minimum wage, etc.); regional, social and economic, natural and climate and geopolitical conditions and peculiarities.

The main constituent in the system of housing and utilities services tariff policy is setting the tariffs structure, which is formed from economically justified costs for performing the service producer's operating and financial activity (full target prime cost) and part of income.

One should note that the key elements of production prime cost, which is taken into account when forming the tariffs for housing and utilities services are material costs - costs for buying or producing the resources (electric energy, water, gas, heat); other direct material costs, which include the costs for spare parts, combustible and lubrication materials and other material resources, which are not the basis for the service provided; direct costs for labor remuneration; other direct costs (depreciation charges, social payments, etc.); general production costs, connected with production premises maintenance, ensuring the proper labor protection and fire safety conditions, observing the sanitary and environmental norms, etc. Specific characteristics of housing and utilities services companies' activity are taken into account also when forming the material costs: traditional elements of production costs can include the costs for preparing the houses for exploitation in winter; for current repair and houses' maintenance; costs for planting and protecting green plantations; costs for materials for sprinkling the territories in winter; costs for common areas' lighting; costs for accommodation, provided to workers of housing and utilities services sector for free or on a preferential basis; payment for services to third-party companies (snow removal, wastewater treatment, 
garbage removal and disposal, etc.). Besides, the tariff includes costs for management and sales, as well as other operating and financial costs (Nekhaychuk, n.d.).

The income, as a tariff structure constituent, is formed based on the justified profitability level taking into account the category of service consumer (population, production enterprise, budget institution, and other consumers), as well as opportunities for housing and utilities services sector subject to pay income tax and ensure the technical re-equipment process. Herewith, the calculated and set profitability level of respective services should be within the limits set by the current legislation on regulating the prices and tariffs for housing and utilities services.

Also, to ensure providing the competitive and quality housing and utilities services, producers of such service can include the investment constituent in the tariff, at the account of which there takes place modernization and renewal of material and technical base, implementation of energy and resource-saving technology. One should note that such practice, on the one hand, favors the improvement of housing and utilities services sector activity effectiveness, decrease of services' material capacity; however, it can cause temporary increase of debt on the part of consumers for housing and utilities services provided.

To ensure the stable and continuous process of housing and utilities companies' activity and taking into account the limited effect on the opportunity for setting the tariffs, which will enable to reimburse the costs for producing them, the state grants the subsidies and other types of state financial support to reimburse the differential.

Also, it is important to pay attention to the fact that, according to the Law of Ukraine "On local self-government", main funds in housing and utilities services sector were transferred from state to communal ownership, and the tariffs setting functions were passed to local authorities and state administrations depending on the company ownership form (Rudchenko, 2011). That is why, the prices (tariffs) for services that the housing and utilities companies of respective territorial community provide are set by local executive authorities, and for ser- vices that the institutions and organizations, which are not communally owned, provide, the tariffs are set by Council of Ministers of the Autonomous Republic of Crimea, regional, Kyiv and Sevastopol city state administrations, as agreed by executive local authorities. Along with that, other normative and legal acts also authorize the executive bodies and local authorities to set and regulate the prices (tariffs) for housing and utilities services, in particular, Laws of Ukraine "On local state administrations", "On drinking water and drinking water supply", "On natural monopolies" and Law of Ukraine "On housing and utilities services", where the legal relations, which appear between among the producers, executors, consumers when creating, providing, and consuming the housing and utilities services, are the subject of regulation (Legislation of Ukraine, 2014).

Thus, studying the peculiarities of financial relations management and highlighting the problems, which cause the decrease of housing and utilities companies functioning effectiveness, enable to reveal the meaningful characteristics and define the directions for increasing the economic entities' activity financial support in this sector.

One of the conditions for forming a "healthy" society is the proportional ratio between the income and tariff scale for main housing and utilities services. During the last decade, one observes constant increase of tariffs for main housing and utilities services. The main reasons for such situation are artificial tariffs containment in the past, which did not comply with real cost of services, insufficient volume of state subsidies, which in the Soviet times and in Independent Ukraine times, were directed towards reimbursing the cost of housing and utilities services and modernizing the networks and equipment; change of price for main resources, which are involved in providing the housing and utilities services, in other words, it is consumer price index; quality and timeliness of providing the housing and utilities services.

First of all, state tariff policy plays a social role, as excessive tariff burden can provoke the population migration. That is why, when setting new tariffs, the state should obligatorily take into account this detail, especially, it is relevant in modern conditions of Ukraine's development. According to 
Table 1. Separation of powers at regional, district, and local levels in terms of setting the tariffs for housing and utilities services

\begin{tabular}{l:l}
\hline Level of management & \multicolumn{1}{c}{ Powers } \\
\hline Licensing of different economic entities' economic activity whose responsibilities include providing the \\
centralized water supply services, which include production, transportation, and supply of drinking \\
water to consumers, and/or centralized sewerage, which is accompanied by expulsion and/or cleaning of \\
communal and other sewage \\
Establishing control over prices/tariffs for housing and utilities services and monitoring the status of \\
payments for them \\
Building the interaction with local authorities on the issues of providing the housing and utilities services \\
and regulating prices/tariffs within their powers \\
Defining the tariffs for housing and utilities services that the companies provide, which are in joint \\
ownership of territorial communities, with district of regional council representing their interests, as \\
well as economic entities, which manage (exploit) the integral asset portfolios of such companies \\
Defining the tariffs for household, housing and utilities (except for tariffs for heat energy, centralized \\
water supply and sewerage, waste processing and disposal, centralized heating services, centralized \\
cold water supply services, centralized hot water supply services, sewerage services (using the house \\
systems), which are set by National Energy and Utilities Regulatory Commission, transport and other \\
services
\end{tabular}

current Regulations on the National Energy and Utilities Regulatory Commission (Legislation of Ukraine, 2014), its competencies include rights such as setting the prices (tariffs) for electric energy, tariffs for its transfer and supply; defining the prices for self-produced commodity natural gas for subjects, defined by the law; setting the retail prices for natural gas, which is used for population needs; defining the tariffs for heat energy, which is produced at heat power plants, nuclear power plants, co-generation stations, and the stations with the use of non-traditional or renewable energy sources; setting the tariffs for housing and utilities services for subjects of natural monopolies and economic entities at related markets, with this authority licensing their activity.

In the context of decentralization reform, one should understand the mechanism of further price setting for a range of housing and utilities services (it is about powers of regional, district administrations and local authorities). The systematized information about their powers is presented in Table 1.

Among the powers of the bodies, relates to forming the tariff policy for housing and utilities services at the regional, district, and local management level, there is providing the services to those economic entities that do not directly report to National Energy and Utilities Regulatory Commission.
When it comes to forming a tariff for this or that housing and utilities service, one should clearly understand what does it consist of - which structural elements are obligatory when forming the service cost. The simplified scheme for forming the tariff for any housing and utilities service is presented in Figure 1.

Thus, the tariff consists of three main parts: costs, income, and value added tax (VAT). Usually, the costs are more than $80 \%$ of all tariff and include the costs for electric energy, labor remuneration, fuel, etc. As a tariff constituent, income plays the role of investment and is used for making more technically equipped and improving the networks and direct support in providing the services. In the tariff structure, the investment constituent can be present minimally or be absent at all. According to the mentioned tariff constituents, it is clear that its increase is based on the increase of the very costs part.

Let us consider more specific example - defining the tariff for heat energy in Lviv region (Figure 2). The percent, presented in each block, indicates the share for each item, included in the tariff.

The biggest part in the tariff structure (94.6\%) is direct cost of the service itself whose large proportion depends on its production price (84.2\%). This percent distribution of tariff structure will not significantly differ also for other regions of Ukraine. 


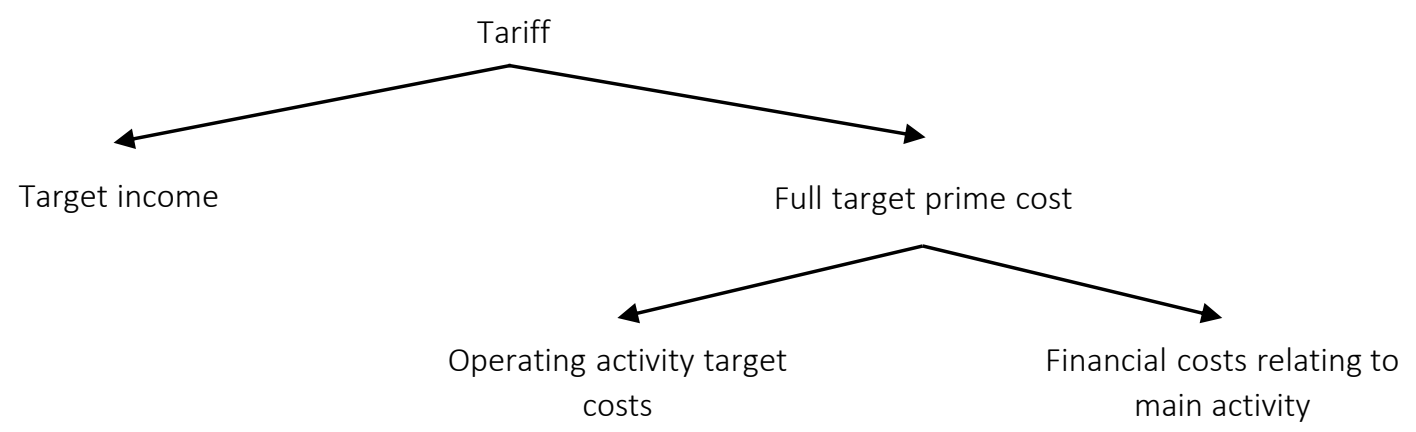

Figure 1. Scheme for forming the tariff for housing and utilities services

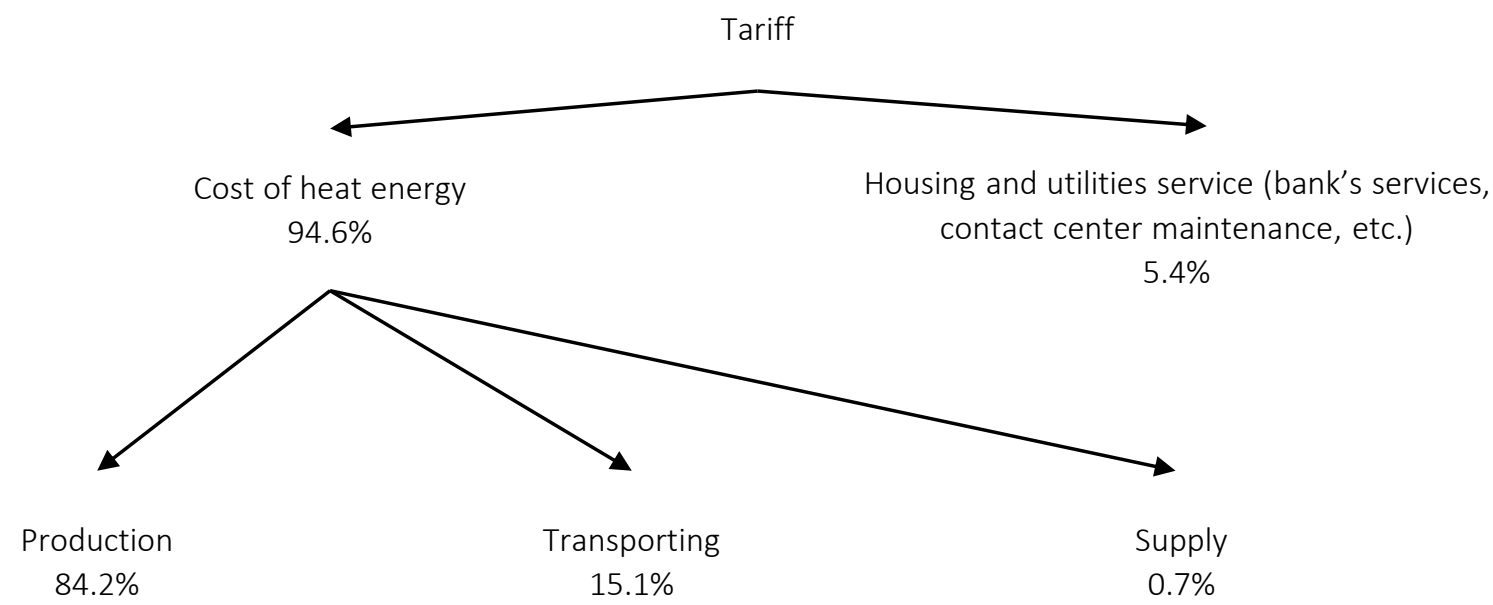

Figure 2. Tariff structure by the example of defining the tariff for heat energy in Lviv region

\section{CONCLUSION}

When defining the index of Ukrainian population tariff burden, it was found out that for all country's regions, its value is rather high. Population's tariff burden creates a threat of social tension aggravation and hinders its effective development. Stimulating regulation should become one of the principles for tariff formation. The essence of this principle lies in regulating the economic entities' activity. Stimulating regulation showed itself to be good in international regulatory practice, as it motivates the economic entities to effectively use the resources and favor the increase of their activity effectiveness as a whole. Such a way of tariff formation should help in eliminating one of the reasons for crisis technical state in heat supply sector infrastructure. The main problem in this very sector is that main part of main means was created a very long time ago and at the account of inflation processes, taking place in Ukraine, now their cost is significantly lower than market equivalent. Besides, one should also consider successful global and European experience in regulating the tariffs for services that the subjects of natural monopolies provide, concerning the depreciation accrual processes, where one uses fair value of respective assets, which are used when regulating the activity ("regulatory assets base"). 


\section{REFERENCES}

1. Beaufils, T., \& Pineau, P.-O. (2019). Assessing the impact of residential load profile changes on electricity distribution utility revenues under alternative rate structures. Utilities Policy, 61. https://doi.org/10.1016/j. jup.2019.100959

2. Didenko, L. V., \& Holovenko, I. P. (2014). Mistsevi pozyky yak dzherelo zaluchennia finansovykh resursiv do mistsevykh orhaniv vlady [Local loans as a source of financial resources attraction to local authorities]. Zbirnyk naukovykh prats Natsionalnoho universytetu Derzhavnoi Podatkovoi Sluzhby Ukrainy - Collection of scientific papers of the National University of the State Tax Service of Ukraine, 2, 57-66. (In Ukrainian). Retrieved from http://www.irbis-nbuv.gov. ua/cgi-bin/irbis_nbuv/cgiirbis_64. exe?I21DBN=LINK\&P21DBN= UJRN\&Z21ID $=\& S 21 \mathrm{REF}=10 \& S$ $21 \mathrm{CNR}=20 \& S 21 \mathrm{STN}=1 \& S 21 \mathrm{FM}$ $\mathrm{T}=\mathrm{ASP} \_$meta\&C21COM=S\&2 $\mathrm{S} 21 \mathrm{P} 03=\mathrm{FILA}=\& 2$ S21STR=znpnudps_2014_2_7

3. Fuentes-Cortés, L. F., FloresTlacuahuac, A., \& Ponce-Ortega, J. M. (2019). Integrated utility pricing and design of water-energy rural off-grid systems. Energy, 177, 511-529. https://doi.org/10.1016/j. energy.2019.04.026

4. Kireitsev, H. H. (2002). Finansy pidpryiemstv [Business finance] (268 p.). Kyiv: CUD. (In Ukrainian).

5. Klien, M., \& Michaud, D. (2019). Water utility consolidation: Are economies of scale realized? Utilities Policy, 61. https://doi.org/10.1016/j. jup.2019.100972

6. Kozachok, I. A. (2011). Formuvannia ta upravlinnia efektyvnym vykorystanniam finansovykh resursiv pidpryiemstva [Forming and managing the efficient use of enterprise financial resources]. Humanitarnyi Visnyk ZDIA - ZSEA Humanitarian Bulletin, 47. (In Ukrainian). Retrieved from http://www.zgia.zp.ua/ gazeta/VISNIK_47_277.pdf

7. Legislation of Ukraine. (2014). Polozhennia pro Natsionalnu komisiiu, shcho zdiisnuie derzhavne rehuliuvannia u sferakh enerhetyky ta komunaknykh posluh [Regulations on the National Energy and Utilities Regulatory Commission]. (In Ukrai- nian). Retrieved from https://zakon. rada.gov.ua/laws/show/715/2014

8. Mamonova, K. A., \& Konoplina, O. O. (2013). Stan ta osoblyvosti funktsionuvannia zhytlovo-komunalnoho kompleksu Ukrainy [State and features of housing and utilities complex of Ukraine functioning]. Ekonomika ta upravlinnia pidpryiemstvamy mashynobudivnoi haluzi: problemy teorii ta praktyky - Economics and Management of Engineering Enterprises: Problems of Theory and Practice, 2(22), 29-39. (In Ukrainian). Retrieved from http://www.irbis-nbuv.gov.ua/ cgi-bin/irbis_nbuv/cgiirbis_64.ex e?I21DBN=LINK\&P21DBN=U $J R N \& Z 21 I D=\& S 21 R E F=10 \& S 2$ $1 \mathrm{CNR}=20 \& S 21 \mathrm{STN}=1 \& S 21 \mathrm{FM}$ $\mathrm{T}=\mathrm{ASP} \_$meta\&C21COM=S\&2_ $\mathrm{S} 21 \mathrm{P} 03=\mathrm{FILA}=\& 2$ S21STR=eupmg_2013_2_5

9. Michelfeldera, R. A., Ahernb, P., \& D'Ascendis, D. (2019). Decoupling impact and public utility conservation investment. Energy Policy, 130 311-319. https://doi.org/10.1016/j. enpol.2019.04.006

10. Mosquera Gutierres, J. C., Leme, R. C., Mota, R. L. M., \& Santos, P. E. S. (2019). Regulatory efficiency decomposition for utilities' parallel subsystems. Operational Research An International Journal. https://doi. org/10.1007/s12351-019-00454-8

11. Nekhaychuk, Yu. S. (n.d.). Otsenka finansovoho obespecheniya predptiyatiy zhilishchno-kommunalnoho khozyaystva $v$ AR Krym i puti ego uluchsheniya [Assessing the financial support of housing and utilities companies in the Autonomous Republic of Crimea and ways of its improvement]. (In Russian).

12. Nielsen, T. (2019). Taxpayer Owned Utilities: Restoring the Appropriate Balance Between Risk and Reward with Respect to Investor Owned Utility Companies. Arizona State University Corporate and Business Journal, Forthcoming. Retrieved from https://ssrn.com/ abstract $=3478835$

13. Poddierogin, A. M., Bilyk, M. D., Buriak, L. D. et al. (2008). Finansy pidpryiemstv [Business finance] (7th ed.) (522 p.). Kyiv: KNEU. (In Ukrainian).
14. Rábago, K. R., \& Valova, R. (2018). Revisiting Bonbright's principles of public utility rates in a DER world. The Electricity Journal, 31(8), 9-13. https://doi.org/10.1016/j. tej.2018.09.004

15. Rudchenko, I. V. (2011). Udoskonalennia mekhanizmu upravlinnia finansovymy resursamy pidpryiemstva [Improving the mechanism of managing the enterprise financial resources. Suchasni pytannia ekonomiky i prava - Modern Issues of Economics and Law, 1, 16-19. (In Ukrainian). Retrieved from http:// nbuv.gov.ua/UJRN/Spep_2011_1_5

16. Rybalko, N. O. (2009). Finansovi resursy pidpryiemstv: hroshovi koshty chy shchos bilshe? [Enterprise Financial Resources: Money or Anything More?] Investytsii: praktyka ta dosvid - Investment: Practice and Experience, 14, 28-31. (In Ukrainian). Retrieved from http://www.investplan.com.ua/ pdf/14_2009/10.pdf

17. Salisbury, M., \& Toor, W. (2016). How and why leading utilities are embracing electric vehicles. The Electricity Journal, 29(6), 22-27. https://doi.org/10.1016/j. tej.2016.07.004

18. Sokyrynska, I. H. (2003). Diahnostyka finansovoho zabezpechennia diialnosti pidptyiemstva [Diagnosis of enterprise activity financial support]. Finansy Ukrainy Ukrainian Finance, 1, 89-93. (In Ukrainian).

19. Worstall, T. (2013). Which Should We Have: Public Utilities or Regulated Private Monopolies? Retrieved from https://www.forbes. com/sites/timworstall/2013/03/24/ which-should-we-have-publicutilities-or-regulated-privatemonopolies/\#16cd83d14263

20. Zubko, O. V. (2011). Mozhlyvosti vprovadzhennia zarubizhnoho dosvidu upravlinnia sektorom ZHKKH v Ukraini [Possibilities of implementing foreign experience of managing the housing and utilities services sector in Ukraine]. Visnyk Zaporizkoho Natsionalnoho Universytetu - Bulletin of Zaporizhzhia National University, 1(9), 218-221. (In Ukrainian). Retrieved from http:// web.znu.edu.ua/herald/issues/2011/ eco_2011_1/2011_1/218-221.pdf 